\title{
Ultrastructural Analysis of Pseudorabies Virus Infection in IB- RS-2 Cell Line and with Treatment by Persea americana Extract
} Isabela Cristina Simoni ${ }^{1}$, Joaquim Moraes de Oliveira ${ }^{2 *}$, Ana Paula de Almeida ${ }^{3 \delta}$, Sônia Soares Costa ${ }^{4}$

\author{
${ }^{1,2}$ Centro de Pesquisa e Desenvolvimento em Sanidade Animal, Instituto Biológico, São Paulo,SP, Brazil \\ ${ }^{3,4}$ Instituto de Pesquisas de Produtos Naturais, Universidade Federal do Rio de Janeiro - UFRJ, Rio de Janeiro, RJ, Brazil \\ ${ }^{\delta}$ Current address: Universidade Severino Sombra, Vassouras, RJ, Brazil \\ Current address: Universidade Sant'Anna, SP, São Paulo, Brazil
}

\begin{abstract}
In this study, we focused on the cycle of replication of the Pseudorabies virus (PrV) in the swine IB-RS-2 cell line in absence or in presence of an infusion from Persea americana leaves. The ultrastructure of the Nova Prata strain virus presents the typical characteristics of Varicelovirus as well as lytic replication with total cell destruction between 18 and 24 hours post-infection (pi). Adsorption is immediate followed by fusion penetration of the virus membranes with those of the host. The capsid once inside the cell migrates to the nucleus where it disappears. Precursor viral particles appear from 4 hours and will form the nuclear crystalloids. The capsids with the viral DNA incorporated migrate to the nuclear membranes where they receive viral envelope after de-envelopment and re-envelopment constituted by cytoplasmic membranes. Then the virions appear grouped in vesicles that merge with the plasma membrane and finally are released out of the cell and become associated with it. Infected cells in the presence of an infusion of Persea americana leaves show few viral particles and many cells without signs of infection. In the initial stages of replication, they are shown pleomorphic with a different morphology when compared with the control. At 7 h post-infection double core with a single envelope are found both between the nuclear membranes and in the cytoplasm of the cell. These findings indicate that the extract may be interfering with virus replication as well as useful in detecting possible targets of inhibition.
\end{abstract}

Keywords-PrV; Aujeszky's disease virus; IB-RS-2 swine cell line; viral ultrastructure; antiviral; Persea americana .

\section{INTRODUCTION}

The Aujeszky's disease virus (ADV) or pseudorabies virus (PrV), also called swine herpesvirus (SuHV-1) and belonging to the family Alfaherpesviridae, occurs in several species of mammals and attacks mainly the central nervous system. It is considered a disease primarily of swine; its control is difficult and causes many economic losses in the stock. The pigs are one of the largest reservoirs of the virus; however, in several mammalian species, such as in cattle, sheep, goats, dogs and cats the disease can also occur (Pomeranz et al., 2005; Nauwynck et al., 2007).

In this study, the strain Nova Prata isolated in Brazil in 1956 from cattle infected with PrV was investigated (Fonseca et al., 2010).

Studies in the literature describe the morphology of the virus mainly in infected cells (Granzow et al., 1997; Johnson and Baines, 2011; Goldsmith et al., 2013). The herpesviruses consist of four distinct structural components: the viral core composed of a double-stranded DNA genome and enclosed by icosahedral capsid to form the nucleocapsid, and the tegument that is a protein matrix surrounded by the viral membrane or viral envelope (Boldogköi and Nógrádi, 2003; Pomeranz et al., 2005; De Clerq and Li, 2016). The replication cycle of the virus, have been well studied in cultured cell systems and can serve as a template for didactic and illustrative purposes, as well as for the study of targets for blockade using both synthetic and natural antiviral drugs (Goldsmith et al., 2013; Kalu et al., 2014; Paulini, 2015).

Among the natural products with antiviral properties, aqueous leaf extract (infusion) from Persea americana showed strong action on PrV with effective inhibition when the extract was added simultaneously to the virus inoculation in IB-RS2 cell line (Koseki et al., 1990; Almeida et al., 1998). In addition, Simoni et al. (1996) showed a reduction of viral infectivity of 1.5 $\log$ after 30 minutes of direct incubation with the virus.

The present study aimed to illustrate by electronic microscopy the steps of the PrV replication in IB-RS-2 infected cell line and to compare it with the replication of the same treated with Persea americana extract. 


\section{MATERIAL AND METHOD}

The Pseudorabies virus (PrV) strain Nova Prata (Fonseca et al., 2010) was provided by the Desidério Finamor Veterinary Research Institute (IPVDF-RS, Brazil) and had 20 passages in the RK-13 rabbit kidney line. Then, it was propagated in the IB-RS-2 clone 13 porcine and the titer obtained was $10^{8} \mathrm{TCDI}_{50} / \mathrm{ml}$.

The plant extract used in this study is an infusion of Persea americana leaves was prepared as described by Simoni et al. (1996). Dried and powdered leaves were extracted by infusing with boiling distilled water at $10 \%(\mathrm{w} / \mathrm{v})$ and were used at the $1.25 \%$ non-cytotoxic concentration (MNTC). This MNTC determined by viewing under the Olympus inverted optical microscope the appearance of treated cells in comparison with that observed for control cells without extract.

IB-RS-2 C-13 porcine kidney cells maintained in minimal Eagle medium (MEM) plus 10\% fetal bovine serum (SFB) were seeded for $24 \mathrm{~h}$ with $1.2 \times 10^{5}$ cells per flask of $25 \mathrm{~cm}^{2}$ capacity. The confluent cell monolayers were then washed with Hanks physiological solution and subjected to the following treatments:

1) Cells infected with $200 \mu \mathrm{L}$ of viral suspension;

2) Cultures controls where $200 \mu \mathrm{L}$ of MEM were added;

3) Control cultures where $200 \mu \mathrm{L}$ of plant extract were added

4) Cells infected with $100 \mu \mathrm{L}$ of viral suspension and added with $100 \mu \mathrm{L}$ of plant extract

5) Cells infected with $200 \mu \mathrm{L}$ of a mixture composed by $100 \mu \mathrm{L}$ of viral suspension incubated at $37^{\circ} \mathrm{C}$ with $100 \mu \mathrm{L}$ of plant extract for $1 \mathrm{~h}$.

At 0 min, 1, 2, 4, 6, 7, 8, 18 and 24 hours post-infection (pi) intervals at $37{ }^{\circ} \mathrm{C}$, the cells were washed twice with physiological solution, carefully collected from the surface of the flasks by scraping and prepared to be examined under the transmission electron microscope. The flasks of $0 \mathrm{~min}$ pi were collected shortly after inoculation and rinsing with physiological solution and the remaining flasks were washed with Hanks's solution. After $1 \mathrm{~h}$ of incubation, MEM without SFB (treatments 1,2 and 5) was added to cell monolayers or plant extract (treatments 3 and 4).

Prior to microscopy processing all cell cultures were observed under the inverted optical microscope to check for possible cellular changes as well as the cytopathic effect (CPE) caused by the virus on the infected cells and also to compare with the infected cells in the presence of extract.

The cells harvested for ME were centrifuged at low speed and each procedure was washed with physiological solution. A solution containing $3 \%$ glutaraldehyde in $0,1 \mathrm{M}$ phosphate buffer, $\mathrm{pH} 7.2$, was added to the pellet over night at $4{ }^{\circ} \mathrm{C}$. The cells were then washed and fixed with $1 \%$ aqueous osmium tetroxide for $2 \mathrm{~h}$ at $4{ }^{\circ} \mathrm{C}$, dehydrated and soaked with Spurr's resin at $65{ }^{\circ} \mathrm{C}$ for $72 \mathrm{~h}$. The materials were sectioned with anultratome LKB III and contrasted with $2 \%$ uranyl acetate for 20 min. and Reynold's lead citrate for 5 min. prior to observation under the Philips EM 300 electron microscope.

\section{RESULTS AND DISCUSSION}

The steps of the PrV replication in IB-RS-2 infected cells observed by means of Transmission Electronic Microscopy (TEM), in the presence or not of a Persea americana leaf infusion (plant extract), are shown in Figures 1-5 and commented below.

Figure 1 shows the IB-RS-2 lineage observed under the light microscope where uninfected cells (treatment 2) form a monolayer (Fig. 1a). Uninfected cells and cells in the presence of plant extract (treatment 3) did not exhibit a cytotoxic effect. They presented a similar appearance to that observed for control cells without plant extract with the preserved organelles
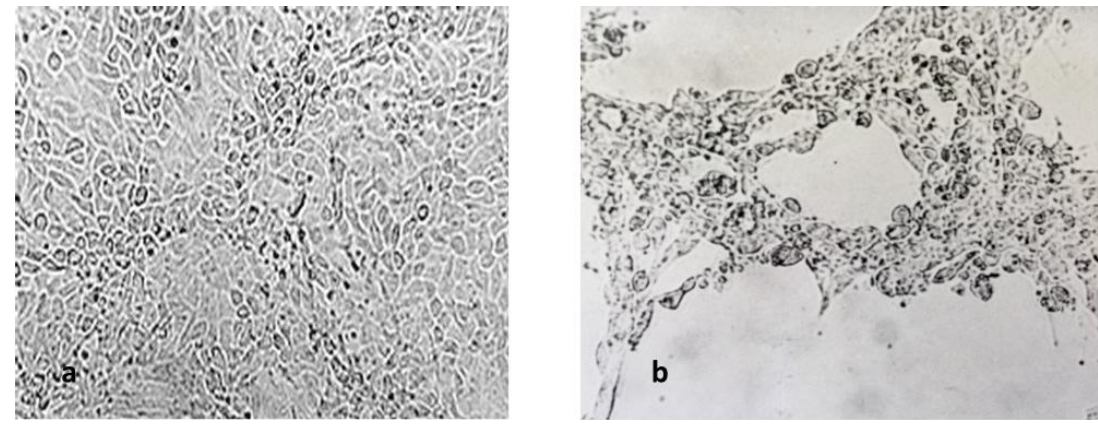

FIGURE 1: MONOLAYER OF IB-RS-2 CELL LINE A) NON INFECTED CELL LINE. B) INFECTED CELLS WITH PSEDORABIES VIRUS (PRV). MAGNIFICATION ABOUT 100X 
The infected cells without plant extract, when observed under the light microscope (treatment 1), did not show changes in their morphology before $6 \mathrm{~h} \mathrm{pi}$, while the infected cells in the presence of plant extract (treatments 4 and 5) did not show changes in their morphology after $7 \mathrm{~h}$ pi.

The monolayers with no plant extract (treatment 1) started to show morphological changes after 6 h pi, initially with the formation of some groups presenting a bulky aspect, contrasting with the rest of the monolayer cells. Mello \& Koseki, 1998 also observed discernible changes at $6 \mathrm{~h}$ after infection studying GBK cells infected with the same strain Nova Prata seen in nuclear phenotypes using Feulgen-stained preparations.

Foci of cytopathic effect were observedat light microscope with $8 \mathrm{~h}$ pi showing many rounded swollen cells and some empty spaces caused by cellular retraction. The evident degeneration process occurred at $18 \mathrm{~h}$ pi where a large number of cells (75\% of the monolayer) was already detached from the surface of the flask (Fig. 1b).

Uninfected cells (treatment 2) when observed at TEM showed the ultrastructures are well preserved with evident and numerous mitochondria, in addition to several cellular polysomes, indicating intense protein synthesis (Fig. 2a).
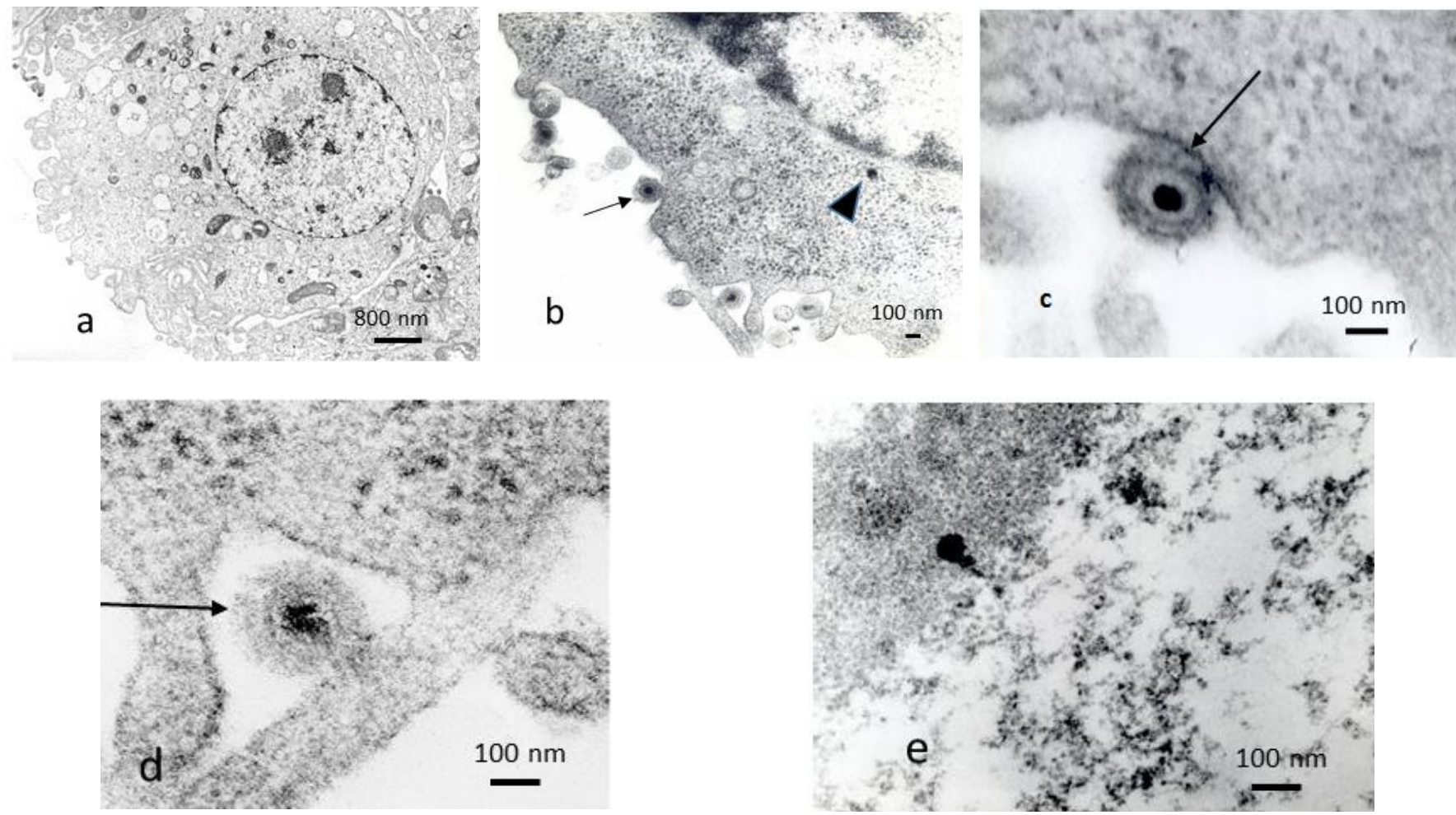

FIGURE 2: THIN SECTION ELECTRON MICROGRAPHS OF UNINFECTED IB-RS-2 CELL LINE. (a) PRV IMMEDIATELY AFTER THE VIRUS INOCULATION. (b) SHOWING VIRUS PARTICLES ATTACHED TO PLASMA MEMBRANE OF INFECTED CELLS (ARROW) AND INTRACYTOPLASMIC NUCLEOCAPSID (ARROWHEAD). HIGHER MAGNIFICATION OF A CELL IN (b) SHOWING ELECTRON-DENSITY OF PLASMA MEMBRANE (ARROW) (c). HIGHER MAGNIFICATION OF A CELL IN (b) SHOWING MEMBANE FUSION (ARROW) (d) NUCLEOLUS OF INFECTED IB-RS-2 CELL WITH PrV AT 4 H POST-INFECTION (e).

Infected cell cultures exhibited extracellular mature virions (Fig. 3g) measuring around $200 \mathrm{~nm}$. This size corresponds to those described in other studies (Pomeranz et al., 2005; Nauwynck et al., 2007; Cardone et al., 2012).

Ultrastructural examination of infected cells at the very beginning of the infection in the first 10 min reveals the immediate adsorption of virions that appear to be bound to the plasma membrane (Fig. 2b), or even electron-dense virus particles inside the cells without the viral envelope (Fig. 2b). Holmes \& Watson (1963) also observed in the early stages of herpes virus infection in BHK-21 cells viral particles inside and outside the cell. Granzow et al. (1997) found that the PrV entry into the cell is very fast and occurs in the first minutes. Frampton et al. (2010) report that after the fusion of the equine herpesvirus and its penetration into the cell, the viral particle in the cytoplasm migrates to the nucleus by using the microtubules such as dinein for its transport and efficient arrival to the nucleus. In addition, EHV-1 induces acetylation of this tubulin within the first 15 min of infection. 
A virion can be seen in contact with the cell membrane with a higher electron-density region indicating a change caused by the association of the viral particle with the host cell (Fig. 2c). A virioncan be seen in an extension of a cell in which the fusion of a virion membrane with the cellular membrane is occurring (Fig. 2d). Morgan et al., 1968 also described the first stage of HSV-1 entry in Hela cell line characterizedby disintegration of the viral envelope adjacentto the cell wall.

Karasneh\& Shukla (2011) reported that herpesviruses enter into the cell in various ways and these steps comprise the binding of the viral particle to the host cell surface, interaction with the specific entry receptor, particle internalization, and membrane fusion.

A detail of a cell after $4 \mathrm{~h}$ pi with no typical viral structures, but showing electron-dense structures close to the nucleolus in the nucleus of the infected cell can be observed in (Figure 2e). Holmes \& Watson (1963) also reported the disappearance of the virus at penetration soon after entry into the nucleus, in addition to the marked increase of particles after $4 \mathrm{~h}$ of infection.

Wild et al. (2002) described intranuclear nucleocapsids in bovine herpesvirus infected MDBK cells with $4 \mathrm{~h}$ of incubation. The authors also reported that all phases of morphogenesis could be found at any time in the infected cell.

In this study, from $4 \mathrm{~h}$ pi the electronic micrographs also show precursor particles of viruses in the nucleus, which are getting more numerous in the course of the infection. Initially, they appear to be associated with electron-dense intranuclear bodies that resemble nucleoli or are still scattered in the nuclear matrix. These nucleolar structures are due to chromatin marginalization (Fig. 3a, b, c).
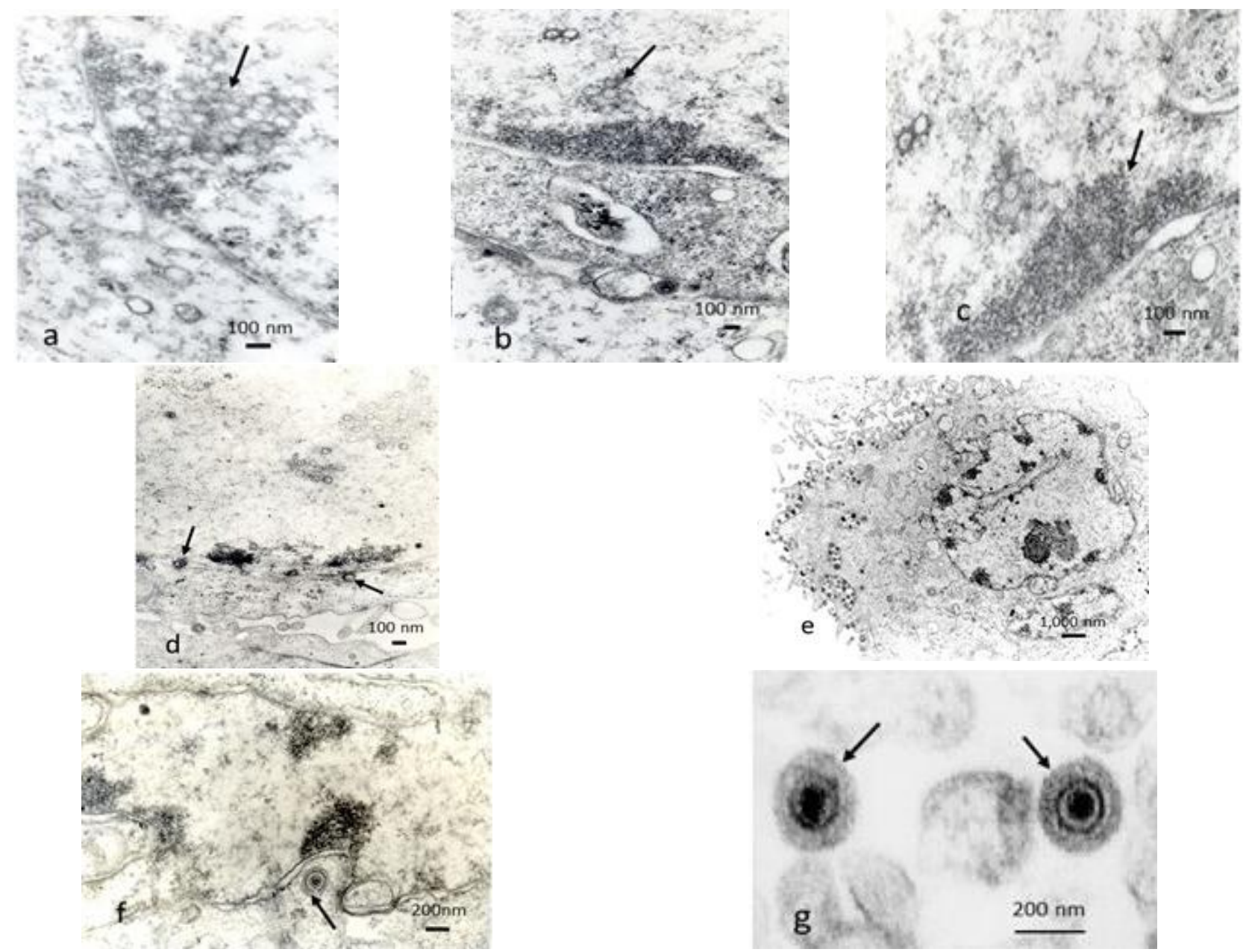

FIGURE 3: ELECTRON MICROSCOPY OF IB-RS-2 INFECTED WITH PrV AT 4-8 H pi, ARROWS INDICATED

MORPHOGENESIS OF INTRANUCLEAR CAPSIDS (a) AND (b). HIGHER MAGNIFICATION OF A CELL IN (b) SHOWING MARGINALIZED CHROMATIN (c). INFECTED CELL SHOWING DISTENDED GAP OF THE NUCLEAR MEMBRANE AND NUCLEOCAPSID IN THE PERINUCLEAR SPACE INDICATED BY THE ARROW (d). INFECTED CELL WITH PrV AT $8 \mathrm{~h}$ pi (e) HIGHER MAGNIFICATION OF A CELL IN (e) SHOWING PARTIALLY ENVELOPED NUCLEOCAPSID UNDERGOING RE-ENVELOPMENT INTO THE CYTOPLASM (f) ULTRASTRUCTURE OF MATURE VIRAL PARTICLE (ARROW) (g). 
Marginalization of chromatin is also observed in the replication of other herpesviruses such as HSV-1. Myllys et al. (2016) related an increase in the nuclear volume and relocation of the host chromatin into the nuclear periphery and in this place, viral nucleocapsid assembly occurs. They also described that there is the formation of channels across the chromatin layer and in this gaps frequently contained viral nucleocapsids allowing for the passage of progeny viruses to the nuclear envelope (Myllys et al., 2016).

Between 4 and $8 \mathrm{~h}$ pi, cells exhibit capsids and pleomorphic cores mostly with little electron density (Fig. 3d). These capsids increase in number and size by forming the crystalloids in the nucleus (Fig. 4a).

In the same infected cell, a series of events occurring at the same time can be observed such as a viral particle that appears in an invagination of the nuclear envelope and seems to be engulfed by membranes in the cytoplasm (Fig. 3e, f).

Capsids with dense cores can be seen between the membranes of the nucleus of the infected cell, suggesting that they may be acquiring envelope from nuclear membranes (Fig. $3 \mathrm{~d}$ ).

We can also observe the presence of many complete virions in vesicles or at the periphery of cells as well as extracellular viruses adhered to the plasma membrane (Fig. 3 e,f,g).

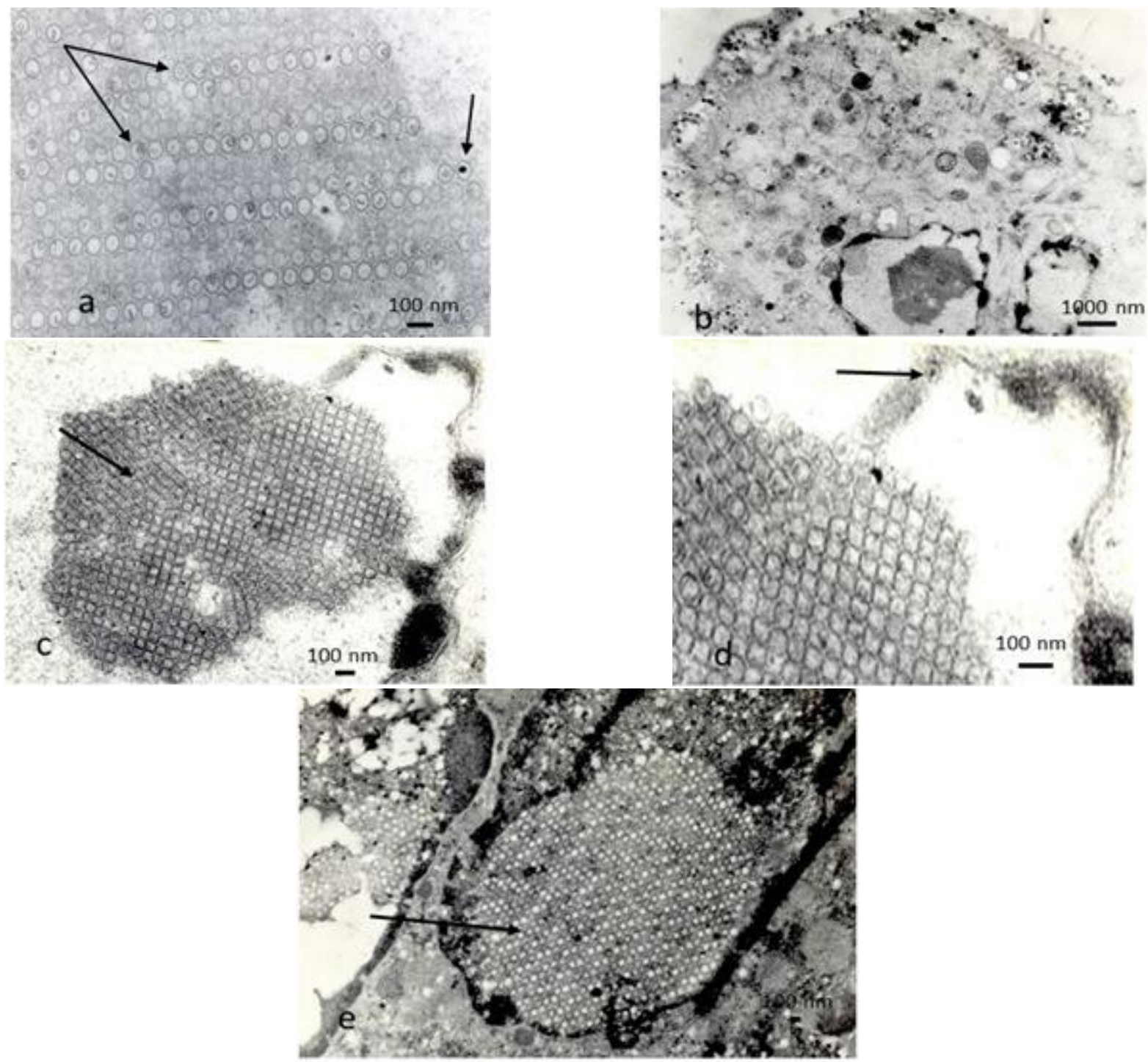

FIGURE 4: ELECTRON MICROGRAPH OF IB-RS-2 INFECTED WITH PrV AT 18-24 h pi, ARROWS INDICATED LARGE NUMBER OF CAPSIDS AGGREGATED AND ARRAYED AS CRYSTALOIDS (a). INTERNAL FEATURES OF INFECTED CELL AT $18 \mathrm{~h}$ pi (b). HIGHER MAGNIFICATION OF A CELL IN (b) SHOWING A PSEUDOCRYSTAL (ARROW) (c) HIGHER MAGNIFICATION OF A CELL IN (c) SHOWING A NUCLEOCAPSID IN A CONNECTION EXTENSION WITH THE NUCLEAR MEMBRANE INDICATED BY A ARROW (d). INFECTED CELL AT 24 pI SHOWING ABSENCE OF ORGANIZED STRUCTURES WITH CELL DESTRUCTION AND A LARGE CRYSTALLOID (ARROW) (e). 
The nuclei of the cells exhibit irregular condensation and marginalization of the chromatin, which become more intense in the later stages of infection. In these nuclei chromatin spraying (Fig. 4b), nucleolus disappearance and invaginations of the nuclear envelope also occur. Such alterations compromise and decharacterize the structures that constitute the nucleus (Fig. $4 \mathrm{~b}, \mathrm{c}, \mathrm{d}, \mathrm{e})$.

In the late stages of infection (18 - $24 \mathrm{~h} \mathrm{pi),} \mathrm{we} \mathrm{can} \mathrm{observe} \mathrm{a} \mathrm{great} \mathrm{destruction} \mathrm{of} \mathrm{the} \mathrm{typical} \mathrm{cellular} \mathrm{structures} \mathrm{and} \mathrm{the}$ presence of aggregates of capsids, the crystalloids, which almost occupy all the space that was previously the nucleus and even the cell.

Most of the micrographs of IB-RS-2 cells infected in the presence of Persea americana extract (treatments 4 and 5) exhibit similar morphology to that observed in uninfected control cells even $7 \mathrm{~h}$ pi (Fig. 5a). In few cells, we verified the presence of infection, but the structural aspect was different from that observed in the infected cells without plant extract. Figure 5c shows a cell after $1 \mathrm{~h}$ of virion infection with an increased core and amorphous capsid exhibiting structure different from that observed in virus control (Fig. 2c; Fig. 3g). Some infected cells present virions and cellular changes resulting from the presence of viral replication, but with different aspects from those observed in infected control cells. Many viral particles exhibit non-electron-density bundles and adhered to the plasma membrane of the cell (Fig. 5b); some $7 \mathrm{~h}$ pi cells show viral particles in vesicles in the nucleus or cytoplasm of the infected cell in pairs or not (Fig. 5d, e).
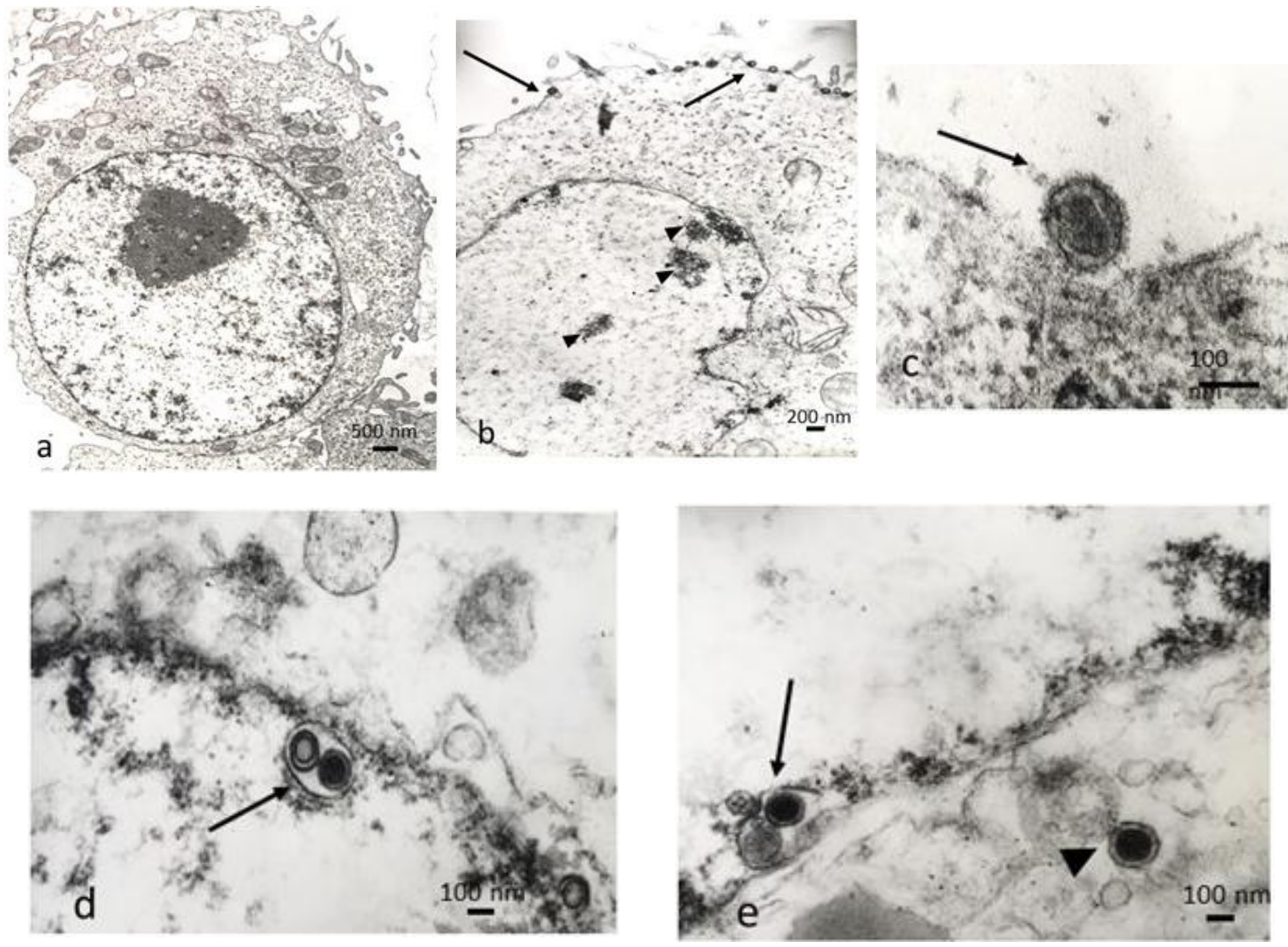

FIGURE 5: ELECTRON MICROGRAPH OF PrV INFECTED CELL AT 7 h pi AND TREATED WITH CRUDE EXTRACT OF PERSEA AMERICANA LEAVES. INFECTED CELLS TREATED WITH EXTRACT SHOWING MORPHOLOGICAL APPEARANCE SIMILAR TO UNINFECTED CELLS (a). INFECTED CELLS TREATED WITH EXTRACT DISPLAYING VIRAL CAPSIDS IN THE NUCLEUS (ARROWHEADS) AND PARTICLES ADHERED TO THE PLASMA MEMBRANE (ARROWS) (b). INFECTED CELLS TREATED WITH EXTRACT SHOWING DEFECTIVE VIRAL PARTICLE (ARROW) (c). INFECTED CELLS TREATED WITH EXTRACT SHOWING DOUBLE CORES IN A SINGLE WRAP IN THE CORE (ARROW) (d). CELL EXHIBITING DOUBLE CORES IN A SINGLE ENVELOPE IN THE SPACE PERINUCLEAR (ARROW) AND A VIRAL PARTICLE INTO THE CYTOPLASM OF THE INFECTED CELL (ARROWHEAD) (e). 
The replication cycle of PrV in IB-RS-2 lineage cells shows the same replication strategies observed in the genus Varicelovirus with a lytic replication (Johnson and Baines, 2011). The IB-RS-2 strain Nova Prata was able to destroy in a few hours the cell monolayer. In the first few minutes of infection, virions are already found inside the cells. Morgan and Howe (1968) have also observed adsorption and penetration of the Sendai virus into the cells at 5 min of inoculation. Soon after the adsorption, the virions underwent various types of changes such as the fusion of the viral envelope in the cellular membrane, dissolution of the capsid and the consequent release of the viral core in the cytoplasm. The viral core in the cytoplasm is not detected because it is difficult to distinguish it from other granules present in both the cytoplasm and the nucleus.

Precursor viral particles appear starting at 4 hours and will form the nuclear crystalloids. The capsids with the viral DNA incorporated migrate to the nuclear membranes where they receive viral envelope after de-envelopment and re-envelopment constituted by cytoplasmic membranes. Then the virions appear grouped in vesicles that merge with the plasma membrane and finally are released out of the cell and become associated with it.

In this study, we confirmed that Persea americana extract inhibited the PrV infections, as described in our previous reports (Koseki et al., 1990; Simoni et al., 1996; Almeida et al., 1998). We report here that Persea americana can affect the virus particle in the adsorption stage, and probably at late stages of virus maturation related with capsid assembly, envelopment and release of infectious virus from the cell.

Antiviral drugs can act at various stages of viral replication and many of them have been described as being against herpesviruses, for instance, the drug Nelfinavir inhibits the maturation and export of HSV-1 (Kalu et al., 2014). However, there are few articles describing the action of plant extracts against herpesvirus on the replication steps studied by TEM (Kerr and Pennington, 1984).There are few reports on the effects of plant extracts on virus infected cells from the point of view of electron microscopy. Studies are needed to better elucidate the mechanisms of action of complex mixtures such as plant extracts and to identify the chemical components responsible for these effects.

\section{CONCLUSION}

Persea americana leaf extract inhibited the replication of $\operatorname{PrV}$, a virus of great importance in animal health. Electron microscopy of wild-type PrV infection generated results that corroborated the results found by other authors for both HSV-1 and those observed in the replication of PrV.

\section{ACKNOWLEDGEMENTS}

Dr Ignez Koseki for the suggestions in the manuscript.

\section{REFERENCES}

[1] A. P.de Almeida, M. M. F. S. Miranda, I. C. Simoni, M. D. Wigg, M. H. C. Lagrota, and S. S. Costa. "Flavonolmonoglycosides isolated from the antiviral fractions of Persea americana (Lauraceae) leaf infusion". Phytother. Res., vol. 12, pp. 562-567, Dec .1998 .

[2] Z. Boldogköi, A. Nógrádi. "Gene and cancer therapy--pseudorabies virus: a novel research and therapeutic tool?" Curr Gene Ther.,vol. 3(2), pp. 155-82, Apr 2003.

[3] G. Cardone, J. B. Heymann, N. Cheng, B. L. Trus, A. C. Steven. "Procapsid Assembly, Maturation, Nuclear Exit: Dynamic Steps in the Production of Infectious Herpesvirions". Adv. Exp. Med. Biol. vol. 726, pp. 423-439, Oct. 2012.

[4] E. De Clercq, G. Lia. "Approved antiviral drugs over the past 50 years”. Clin. Microbiol. Rev., vol. 29, pp. 695-747, July 2016.

[5] A. A. Fonseca Jr, M. F. Carmagos, R. M. F. D’Ambros, A. C. Braga, J.Ciacci-Zanella, M. B. Heinemann, R. C. Leite, J. K. P. dos Reis. "Diagnóstico e genotipagem do vírus da pseudoraiva por nested-PCR e análise de restrição enzimática". Ciência Rural, Santa Maria, v.40, n.4, p.921-927, April 2010.

[6] A.R. Frampton, Jr., H. Uchida, J. von Einem, W. F. Goins, P. Grandi, J. B. Cohen, N. Osterrieder, J. C. Glorioso. "Equine herpesvirus type 1 (EHV-1) utilizes microtubules, dynein, and ROCK1 to productively infect cells". Veterinary Microbiology vol.141 (1-2), pp.12, Feb. 2010.

[7] C. S. Goldsmith, T. G. Ksiazek, P. E. Rollin, J. A. Comer, W. L. Nicholson, T. C.T. Peret, D. D. Erdman, W. J. Bellini, B. H. Harcourt, P. A. Rota, J. Bhatnagar, M. D. Bowen, B. R. Erickson, L. K. McMullan, S. T. Nichol, W-J. Shieh, C. D. Paddock, S. R. Zaki."Cell Culture and Electron Microscopy for Identifying Viruses in Diseases of Unknown Cause". Emerging Infectious Diseases, vol. 19, pp. 886-891, June 2013.

[8] H. Granzow, F. Weiland, A. Jo, B. G. Klupp, A. Karger, T. C. Mettenleiter. "Ultrastructural Analysis of the Replication Cycle of Pseudorabies Virus in Cell Culture: a Reassessment”. Journal of Virology vol.71, pp. 2072-2082, Mar. 1997.

[9] I. H. Holmes, D. H. Watson. "An electron microscope study of the attachment and penetration of herpes virus in BHK21 cells". Virology, vol. 21, pp. 112-123, September 1963. Available in: http://dx.doi.org/10.1016/0042-6822(63)90309-X Accessed: Ago 2017. 
[10] D. C. Johnson and J. D. Baines. "Herpesviruses remodel host membranes for virus egress". Nature Review Microbiology vol.9, pp.382-394, May 2011. Available in: http://www.nature.com/nrmicro/journal/v9/n5/pdf/nrmicro2559.pdf Accessed: Ago 2017.

[11] N. N. Kalu, P. J. Desai, C. M. Shirley, W. Gibson, P. A. Dennis, R. F. Ambindera. "Nelfinavir inhibits maturation and export of Herpes Simplex Virus 1”. Journal of Virology vol. 88, pp. 5455-5461, May 2014.

[12] G. A Karasneh and D. Shukla. "Herpes simplex virus infects most cell types in vitro: clues to its success". Virology Journal vol. 8, pp. 481, Oct. 2011. Available in: https://doi.org/10.1186/1743-422X-8-481 Accessed: Ago 2017.

[13] C. L. Kerr, and T.H. Pennington. "The Effect of Monensin on Virion Production and Protein Secretion in Pseudorabies Virus-infected Cells”. J. Gen. Virol. Great Britain, vol. 65, pp. 1033-1041, 1984.

[14] I. Koseki, I. C. Simoni, I. T. Nakamura, A.B. Noronha, S.S. Costa. "Antiviral activity of plant extracts against aphovirus, pseudorabies virus and pestivirus in cell cutures”. Microbios Letters vol. 44, pp. 19-30, 1990.

[15] M.L.S. Mello and I. Koseki. "Nuclear phenotypes and DNA content in GBK cell line infected with viruses of Aujeszky's disease and bovine diarrhea". Cytobios vol. 95, pp. 111-121, 1998.

[16] C. Morgan and C. Howe. "Structure and development of viroses as observed in the electron microscope. IX. Entry of parainfluenza I (Sendai) virus". Journal of Virology v2: 1122-1132, 1968. Available in: http://jvi.asm.org/content/2/10/1122.full.pdf+html Accessed: Ago 2017.

[17] C.Morgan,H.M. Rose, B.Mednis.“Electron Microscopy of Herpes Simplex Virus I. Entry”. Journal of Virology 2 (5): 507-516, 1968. https://www.ncbi.nlm.nih.gov/pmc/articles/PMC375640/pdf/jvirol00317-0107.pdf Accessed: Ago 2017.

[18] M. Myllys, V. Ruokolainen, V. Aho, E. A. Smith, S. Hakanen, P. Peri, A. Salvetti, J. Timonen, V. Hukkanen, C. A. Larabell, M. Vihinen-Ranta. "Herpes simplex virus 1 induces egress channels through marginalized host chromatin". Scientific Reports, 6:28844, 2016. Available in: doi:10.1038/srep28844 Accessed: Ago 2017.

[19] H.Nauwynck, S. Glorieux, H.Favoreel, M.Pensaert. "Cell biological andmolecular characteristics of pseudorabies virus infections in cell cultures and in pigs with emphasis on the respiratory tract". Veterinary Research, BioMed Central, vol. 38, pp.229-241, 2007.

[20] I. J. Paulini Jr, "Cinética de infecção do vírus vaccinia em células Vero: perspectivas para utilização como modelo experimental na avaliação de drogas anti-orthopoxvírus". ArchivesofVeterinary Science vol. 20, pp. 59-64, 2015.

[21] L.E. Pomeranz, A.E. Reynolds, C.J. Hengartner, et al. "Molecular biology of pseudorabies virus: impact on neurovirology and veterinary medicine". Microbiol. Molecular Biology Review 69 (3): 462-500, $2005 . \quad$ Available in: http://mmbr.asm.org/content/69/3/462\#ref-list-1 Accessed: Ago 2017.

[22] I.C. Simoni, M.J.B. Fernandes, C.R. Gonçalves, A.P. Almeida, S.S. Costa, A.P. Lins. "A study on the antiviral characteristics of Persea americana extracts against Aujeszky's disease virus". Biomedical Letters, vol 54, pp. 173-181, 1996.

[23] P. Wild, E.M. Schraner, D. Cantieni, E. Loepfe, P. Walther, M. Muller, M. Engels. "The significance of the Golgi complex in envelopment of bovine herpesvirus 1 (BHK-1) as revealed by cryobased electron microscopy". Micron vol.33, pp. 327-337, 2002. 